\title{
Cultivation Methods for Leafy Vegetables and Tomatoes with Low Potassium Content for Dialysis Patients
}

\author{
Atsushi Ogawa, Takako Eguchi and Kyoko Toyofuku \\ Department of Biological Production, Akita Prefectural University, \\ 241-438 Shimoshinjyou-nakano, Akita 010-0195, Japan
}

(Received August 24, 2012; Accepted October 10, 2012)

\begin{abstract}
The objective of this study was to establish a cultivation method for leafy vegetables and tomatoes with low potassium content for dialysis patients who are restricted potassium intake, while still maintaining normal plant growth. Three types of leafy vegetables were grown hydroponically with no potassium application during the latter half of their growth period. Tomatoes were grown hydroponically under two different conditions 1) in a nutrient solution without potassium, and 2) in a nutrient solution alternated every week with and without potassium. The potassium content of leafy vegetables in the potassium restricted group was $30-40 \%$ of the control, with no change in plant growth. The potassium content of the tomatoes in the potassium restricted group was also reduced to $50-89 \%$ of the control. There was no change in the fresh weight per fruit of the tomatoes; however, the total yield was reduced. In addition, reduction in the potassium content was accompanied by an increase in the sodium and magnesium content of the leafy vegetables and tomatoes. The increases in sodium and magnesium content occurred to compensate for the decline in potassium content so that the growth of the plant was not inhibited.
\end{abstract}

Keywords : dialysis patients, leafy vegetables, potassium, sodium, tomato

\section{INTRODUCTION}

At 2011, the number of dialysis patients worldwide was approximately 2.16 million (Fresenius Medical Care, 2011). It is estimated that this number has increased 13-fold all over the world in the 30 years between 1980 and 2011 (Fresenius Medical Care, 2011). Because the symptoms of kidney disease are subtle, and one of the most significant primary diseases in kidney disease is diabetes, it is estimated that tens of thousands to several million people have a preliminary stage of kidney disease (Atkins and Zimmet, 2010) ; this suggests a further increase in dialysis patients. Because dialysis patients have dysfunctional potassium excretion mechanisms, there is a possibility of them suffering from serious electrocardiographic abnormalities and heart failure due to hyperkalemia (Putcha and Allon, 2007). Therefore, disturbances in plasma potassium concentration, most commonly hyperkalemia, remain a constant threat to the health of dialysis patients (Spital and Stems, 1988). Potassium intake must be restricted in dialysis patients. Because the vegetables that we generally eat contain high levels of potassium (Weiner and Wingo, 1998), dialysis patients should not eat raw vegetables, they should have them boiled or leached in water to remove excess potassium (Burrowes and Ramer, 2006; 2008). Although potassium content is

Corresponding author: Atsushi Ogawa, fax : +81-18-872-1678, e-mail : 111111@akita-pu.ac.jp 
partially reduced by these methods, the degree of reduction is limited. In addition, other important minerals and vitamins get eluted and disassembled by these methods.

We believe that vegetables cultivated to contain lower potassium levels are beneficial for dialysis patients compared to those cultivated by the general method. The former allows patients to eat raw vegetables in moderation. The potassium content of these vegetables can be reduced even further by boiling or leaching in water. In this study, we examined methods to decrease the potassium content of the edible part of vegetables at harvest by regulating the fertilization system.

Potassium is an essential macronutrient for plant growth (Schachtman and Liu, 1999). Potassium plays a significant physiological role in the metabolism of substances within a cell, such as the maintenance of protoplasmic structure and pH levels (Fageria et al., 2010), and the compatible solutes required for osmotic adjustment (Ogawa and Yamauchi, 2006). Therefore, it is expected that limited supply of potassium will inhibit plant growth. Therefore, it is important to investigate the amount to which the potassium levels can be reduced while still maintaining the optimum levels for plant growth. In our previous study (Ogawa et al., 2007), we showed that the potassium content in spinach could be reduced to as much as $79 \%$ of that of the control with no reduction in fresh weight at harvest, when plants were grown hydroponically with no potassium applications during the latter half of the growth period. The results suggested that it is possible to produce low potassium spinach while maintaining normal plant growth. However, it is not clarified in other vegetables.

The objective of this study was to verify whether the cultivation method established in our previous study (Ogawa et al., 2007) could be applied to other leafy vegetables for the successful cultivation of low potassium content leafy vegetables, without any detrimental effects on plant growth. We aimed to develop a cultivating method for the production of tomatoes with low potassium content, while maintaining normal plant growth. Through these results, we aim to contribute to an improvement in the eating habits of dialysis patients.

\section{MATERIALS AND METHODS}

\section{Plant culture of leafy vegetables}

Red leaf lettuce (Lactuca sativa L. var. crispa cv. Rosanna, The Yokohama Nursery Co., Ltd., Japan), asparagus lettuce (Lactuca sativa L. var. angustana cv. Chima sanchu, Takii Seed Co., Ltd., Japan), and komatsuna (Brassica rapa L. var. perviridis cv. Natsurakuten, Takii Seed Co., Ltd., Japan) seedlings were used for this experiment. Their seeds were embedded in a cube sponge and germinated for ten days in a dark growth chamber at $20^{\circ} \mathrm{C}$. During this period, seminal roots of their seedlings were elongated by approximately $30 \mathrm{~mm}$. The seedlings were transplanted to the water culture system (Aqua Farm; S-type; Asama Engineering Co., Ltd., Japan) in the growth chamber with natural sunlight (2S-153A; Koito Industries, Ltd., Japan). The growth chamber was maintained at $24^{\circ} \mathrm{C}$ during the day and $20^{\circ} \mathrm{C}$ at night with approximately $70 \%$ relative humidity.

For 21 days after transplantation, the plants were grown in the control solution containing 3.0 $\times 10^{-3} \mathrm{M} \mathrm{KNO}_{3}, 2.0 \times 10^{-3} \mathrm{M} \mathrm{Ca}\left(\mathrm{NO}_{3}\right)_{2} 4 \mathrm{H}_{2} \mathrm{O}, 5.0 \times 10^{-4} \mathrm{M} \mathrm{NH}_{4} \mathrm{H}_{2} \mathrm{PO}_{4}, 1.0 \times 10^{-3} \mathrm{M} \mathrm{MgSO}_{4} 7 \mathrm{H}_{2} \mathrm{O}$, $2.6 \times 10^{-5} \mathrm{M}$ Fe-EDTA, $4.6 \times 10^{-6} \mathrm{M} \mathrm{MnCl}_{2} 4 \mathrm{H}_{2} \mathrm{O}, 2.4 \times 10^{-5} \mathrm{M} \mathrm{H}_{3} \mathrm{BO}_{3}, 3.8 \times 10^{-7} \mathrm{M} \mathrm{ZnSO}_{4} 7 \mathrm{H}_{2} \mathrm{O}$, $1.6 \times 10^{-7} \mathrm{M} \mathrm{CuSO}_{4} 5 \mathrm{H}_{2} \mathrm{O}$, and $1.5 \times 10^{-8} \mathrm{M}\left(\mathrm{NH}_{4}\right)_{6} \mathrm{Mo}_{7} \mathrm{O}_{24} 4 \mathrm{H}_{2} \mathrm{O}$ (Ogawa et al., 2007). The $\mathrm{pH}$ of the water solution was adjusted to 6.5 with $0.1 \mathrm{~N} \mathrm{NaOH}$. At 22 days after transplantation, the control solution was substituted with a "no potassium" solution and $3.0 \times 10^{-3} \mathrm{M} \mathrm{NaNO}_{3}$ instead of $\mathrm{KNO}_{3}$. This composition restricted potassium levels, and the $\mathrm{pH}$ of the water solution was adjusted to 6.5 with $0.1 \mathrm{~N} \mathrm{NaOH}$.

In the control treatment, the components of the water solution were not changed until the harvest period. Plants were harvested at 28 days after transplantation for the asparagus lettuce and komatsuna, and at 31 days after transplantation for the red leaf lettuce. 


\section{Plant culture of tomatoes}

Medium-sized tomato (Solanum lycopersicum L. cv. Red Olle, Kaneko Seeds Co., Ltd., Japan) seedlings were used for this experiment. Seeds were sown in a cell tray filled with andosol to produce seedlings. After 28 days, the roots of the seedlings were carefully washed with water to remove soil, and seedlings were transplanted to the water culture system (Waterfarm, General Hydroponics, USA) in a plastic greenhouse. Thirty-five days after transplantation, the control solution (described in the above section) was provided. When the first fruit developed at the first truss, the treatments with potassium restriction was started, as described below.

(1) 0K treatment: The "no potassium" solution described in the above section was provided throughout cultivation.

(2) 1 W0K treatment: The "no potassium" solution and the control solution were alternated each week.

(3) Control: The control solution was provided throughout cultivation.

All lateral shoots were removed. The main shoot of each plant was pinched to the leaf two leaves above the fifth truss. Sixty-four days after transplantation, ripe fruits were harvested.

\section{Measurement}

The fresh weight of the harvested samples was measured. For tomatoes, the soluble solid content (Brix) was also measured by a refractometer. Samples were dried at $80^{\circ} \mathrm{C}$ for $48 \mathrm{~h}$ and dry weight was measured. Samples were heated at $550^{\circ} \mathrm{C}$ for $6 \mathrm{~h}$. The ashes were dissolved with $1 \mathrm{~N}$ $\mathrm{HNO}_{3}$. The concentrations of potassium, calcium, magnesium, and sodium were measured with an atomic absorption spectrophotometer (AA-6800; Shimadzu, Japan) and flame photometry.

\section{RESULTS}

\section{Leafy vegetables}

Table 1 shows the changes in the ion content in the three leafy vegetables at harvest for each treatment. The potassium contents of red leaf lettuce, asparagus lettuce, and komatsuna in the control group were 3,634, 3,709, and 4,226 $\mu \mathrm{g}$ per $1 \mathrm{~g}$ of fresh weight, respectively, and those in the potassium-restricted group were $1,026,1,545$, and $1,315 \mu \mathrm{g}$, respectively. These values represent a significant reduction in potassium levels; $28 \%, 42 \%$ and $31 \%$ of the control, respectively. The sodium content in all plants, and the magnesium contents in the red leaf lettuce and asparagus lettuce were increased significantly when the potassium supply was restricted. Particularly, the sodium content was increased markedly. The sodium contents of red leaf lettuce, asparagus lettuce, and komatsuna in the control group were 77, 38, and $139 \mu \mathrm{g}$ per $1 \mathrm{~g}$ of fresh weight respectively, while that in the potassium-restricted group were 1,031, 477, and 1,692 $\mu \mathrm{g}$, respectively. This represents a 13.4-fold, a 12.6-fold, and a 12.2-fold, respectively, increase as compared with the control group.

Table 2 shows fresh weight, dry weight, and water content at harvest for each treatment group.

Table 1 Changes in potassium, calcium, magnesium and sodium contents ( $\mu \mathrm{g} / \mathrm{g} \mathrm{FW})$ of red leaf lettuce, asparagus lettuce and komatsuna at the harvest as affected by potassium restricted treatment.

\begin{tabular}{lcccccc}
\hline & \multicolumn{2}{c}{ Red leaf lettuce } & \multicolumn{2}{c}{ Asparagus lettuce } & \multicolumn{2}{c}{ Komatsuna } \\
\hline & Control & $\begin{array}{c}\text { Potassium } \\
\text { restricted }\end{array}$ & Control & $\begin{array}{c}\text { Potassium } \\
\text { restricted }\end{array}$ & Control & $\begin{array}{c}\text { Potassium } \\
\text { restricted }\end{array}$ \\
\hline Potassium & $3634 \pm 146$ & $1026 \pm 48^{*}$ & $3709 \pm 230$ & $1545 \pm 90^{*}$ & $4226 \pm 192$ & $1315 \pm 36^{*}$ \\
Calcium & $373 \pm 17$ & $364 \pm 12 \mathrm{NS}$ & $316 \pm 20$ & $287 \pm 11 \mathrm{NS}$ & $1349 \pm 71$ & $1406 \pm 59 \mathrm{NS}$ \\
Magnesium & $375 \pm 15$ & $492 \pm 15^{*}$ & $206 \pm 13$ & $299 \pm 12^{*}$ & $377 \pm 24$ & $416 \pm 20 \mathrm{NS}$ \\
Sodium & $77 \pm 11$ & $1031 \pm 55^{*}$ & $38 \pm 2$ & $477 \pm 37^{*}$ & $139 \pm 11$ & $1692 \pm 60^{*}$ \\
\hline
\end{tabular}

Each value shows the mean \pm standard error $(\mathrm{n}=8)$.

*represents statistical significance at $P<0.05$ compared with control. NS, not significant by t-test. 


\section{A. OGAWA ET AL.}

Table 2 Changes in fresh weight, dry weight and water content of red leaf lettuce, asparagus lettuce and komatsuna at the harvest as affected by potassium restricted treatment.

\begin{tabular}{|c|c|c|c|c|c|c|}
\hline & \multicolumn{2}{|c|}{ Red leaf lettuce } & \multicolumn{2}{|c|}{ Asparagus lettuce } & \multicolumn{2}{|c|}{ Komatsuna } \\
\hline & Control & Potassium & Control & Potassium & Control & Potassium \\
\hline Fresh weight (g) & $53.9 \pm 4.1$ & $50.3 \pm 4.3 \mathrm{NS}$ & $39.8 \pm 4.6$ & $40.6 \pm 3.2 \mathrm{NS}$ & $176.1 \pm 22.0$ & $178.4 \pm 11.1 \mathrm{NS}$ \\
\hline Dry weight (g) & $3.4 \pm 0.2$ & $3.1 \pm 0.3 \mathrm{NS}$ & $1.7 \pm 0.3$ & $1.6 \pm 0.2 \mathrm{NS}$ & $10.4 \pm 1.5$ & $10.2 \pm 0.6 \mathrm{NS}$ \\
\hline Water content $(\%)$ & $93.7 \pm 0.2$ & $93.8 \pm 0.2 \mathrm{NS}$ & $95.7 \pm 0.2$ & $96.0 \pm 0.2 \mathrm{NS}$ & $94.1 \pm 0.2$ & $94.3 \pm 0.2 \mathrm{NS}$ \\
\hline
\end{tabular}

Each value shows the mean \pm standard error $(n=8)$.

NS, not significant compared with control by t-test.

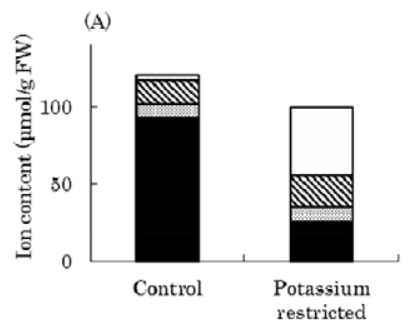

Potassium
$\mathbb{N}$ Magnesium
(B)

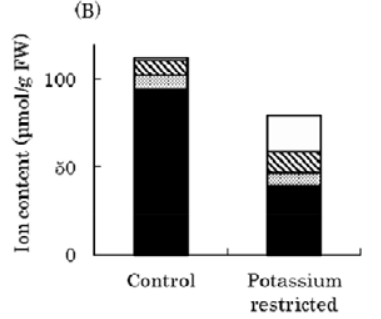

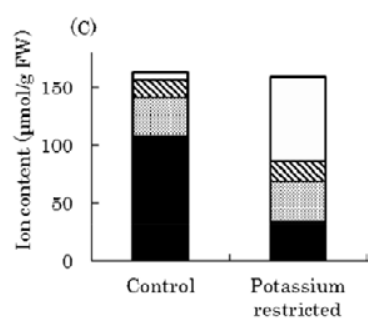

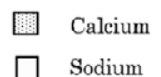

Fig. 1 Changes in total ion contents of potassium, calcium, magnesium and sodium in red leaf lettuce (A), asparagus lettuce (B) and komatsuna (C) at the harvest as affected by potassium restricted treatment.

For all plants, there was no significant difference in these measurements compared with the control. These results showed that there was no change in the plant growth, despite the potassium restriction.

Despite the reduction of potassium supply, plant growth was maintained and some other ion contents were increased. One of the roles of potassium ion is to adjust of osmotic potential. Therefore, the numbers of moles of potassium, sodium, magnesium, and calcium ions per fresh weight were calculated to show the total number of moles of these ions (Fig. 1). The numbers of moles of sodium and magnesium ions were greater in the potassium-restricted group for all plants. However, the total numbers of moles in the potassium-restricted group were $83 \%$ and $71 \%$ of that of the control group in red leaf lettuce and asparagus lettuce, respectively. For komatsuna, the total number of moles in the potassium-restricted group was $98 \%$ of that of the control group.

\section{Tomatoes}

Table 3 shows the changes in ion content in tomatoes at harvest in each treatment group. The potassium contents in the potassium-restricted groups (1W0K and $0 \mathrm{~K}$ treatments) in all trusses were reduced significantly when compared with the control. The potassium content of the control group was $1,551^{-2}, 126 \mu \mathrm{g}$ per $1 \mathrm{~g}$ of fresh weight in each truss. On the other hand, the potassium

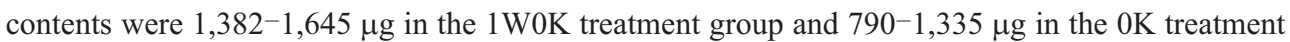
group. The percentages were $74 \%-89 \%$ and $45 \%-73 \%$ of the control group for the $1 \mathrm{~W} 0 \mathrm{~K}$ and $0 \mathrm{~K}$ treatment groups. In the fifth truss of the $0 \mathrm{~K}$ treatment group, no fruit were harvested by the growth inhibition due to the potassium restricted treatment.

Calcium and magnesium content was affected slightly by the treatment with potassium restriction. The calcium content was significantly higher than that in the control group in the third truss of $1 \mathrm{~W} 0 \mathrm{~K}$ treatment and in the first truss of $0 \mathrm{~K}$ treatment. The magnesium content was significantly higher than that in the control group in the fifth truss of $1 \mathrm{~W} 0 \mathrm{~K}$ treatment and in the first and the second trusses of $0 \mathrm{~K}$ treatment. On the other hand, the sodium content was increased drastically 


\section{VEGETABLES WITH LOW POTASSIUM}

Table 3 Changes in potassium calcium, magnesium and sodium contents $(\mu \mathrm{g} / \mathrm{g} \mathrm{FW})$ of tomato at the harvest as affected by potassium restricted treatment.

\begin{tabular}{llccccc}
\hline & Truss & \multicolumn{1}{c}{ 1st } & 2nd & 3rd & 4th & 5th \\
\hline \multirow{5}{*}{ Potassium } & Control & $1825 \pm 35.0 \mathrm{a}$ & $2013 \pm 57.3 \mathrm{a}$ & $2126 \pm 77.9 \mathrm{a}$ & $1747 \pm 37.7 \mathrm{a}$ & $1551 \pm 22.6 \mathrm{a}$ \\
& $1 \mathrm{~W} 0 \mathrm{~K}$ & $1429 \pm 26.2 \mathrm{~b}$ & $1489 \pm 27.2 \mathrm{~b}$ & $1645 \pm 48.1 \mathrm{~b}$ & $1458 \pm 39.7 \mathrm{~b}$ & $1382 \pm 22.7 \mathrm{~b}$ \\
& $0 \mathrm{~K}$ & $1335 \pm 26.5 \mathrm{~b}$ & $1155 \pm 33.2 \mathrm{c}$ & $1072 \pm 48.2 \mathrm{c}$ & $790 \pm 47.5 \mathrm{c}$ & \\
\hline \multirow{3}{*}{ Calcium } & Control & $37 \pm 3.5 \mathrm{a}$ & $59 \pm 16.2 \mathrm{ab}$ & $58 \pm 7.0 \mathrm{a}$ & $74 \pm 4.4 \mathrm{a}$ & $61 \pm 3.7 \mathrm{a}$ \\
& $1 \mathrm{~W} 0 \mathrm{~K}$ & $48 \pm 3.9 \mathrm{a}$ & $53 \pm 7.7 \mathrm{a}$ & $108 \pm 5.0 \mathrm{~b}$ & $84 \pm 3.8 \mathrm{a}$ & $64 \pm 5.7 \mathrm{a}$ \\
& $0 \mathrm{~K}$ & $62 \pm 3.4 \mathrm{~b}$ & $96 \pm 9.2 \mathrm{~b}$ & $81 \pm 6.7 \mathrm{a}$ & $90 \pm 8.3 \mathrm{a}$ & \\
\hline \multirow{5}{*}{ Magnesium } & Control & $75 \pm 2.7 \mathrm{a}$ & $98 \pm 2.7 \mathrm{a}$ & $101 \pm 3.2 \mathrm{a}$ & $99 \pm 3.5 \mathrm{a}$ & $89 \pm 2.2 \mathrm{a}$ \\
& $1 \mathrm{~W} 0 \mathrm{~K}$ & $77 \pm 3.1 \mathrm{ab}$ & $95 \pm 2.2 \mathrm{a}$ & $107 \pm 2.5 \mathrm{a}$ & $97 \pm 2.0 \mathrm{a}$ & $97 \pm 2.2 \mathrm{~b}$ \\
& $0 \mathrm{~K}$ & $85 \pm 2.3 \mathrm{~b}$ & $112 \pm 2.7 \mathrm{~b}$ & $110 \pm 4.5 \mathrm{a}$ & $95 \pm 4.9 \mathrm{a}$ & \\
\hline \multirow{5}{*}{ Sodium } & Control & $47 \pm 5.6 \mathrm{a}$ & $35 \pm 9.6 \mathrm{a}$ & $57 \pm 5.6 \mathrm{a}$ & $75 \pm 3.2 \mathrm{a}$ & $17 \pm 2.2 \mathrm{a}$ \\
& $1 \mathrm{~W} 0 \mathrm{~K}$ & $60 \pm 3.5 \mathrm{a}$ & $69 \pm 3.8 \mathrm{~b}$ & $99 \pm 8.6 \mathrm{~b}$ & $106 \pm 4.4 \mathrm{~b}$ & $32 \pm 2.3 \mathrm{~b}$ \\
& $0 \mathrm{~K}$ & $88 \pm 6.7 \mathrm{~b}$ & $115 \pm 4.5 \mathrm{c}$ & $179 \pm 11.5 \mathrm{c}$ & $160 \pm 13.0 \mathrm{c}$ & \\
\hline
\end{tabular}

Each value shows the mean \pm standard error.

Means followed by the common letters under each trust were not significantly different according to the multiple test of Tukey $(P<0.05)$.

In the 5 th truss of $0 \mathrm{~K}$ treatment, no fruit were harvested.

Table 4 Changes in fresh weight, number of fruit, total fresh weight, soluble solids content and water content of tomato at the harvest as affected by potassium restricted treatment.

\begin{tabular}{clccccc}
\hline & Truss & $1 \mathrm{st}$ & 2nd & 3rd & 4 th & 5 th \\
\hline \multirow{2}{*}{$\begin{array}{c}\text { Fresh weight } \\
\text { (g/fruit) }\end{array}$} & Control & $39.9 \pm 1.7 \mathrm{a}$ & $40.8 \pm 2.0 \mathrm{a}$ & $44.3 \pm 2.1 \mathrm{a}$ & $45.5 \pm 2.0 \mathrm{~b}$ & $46.3 \pm 2.0 \mathrm{a}$ \\
& $0 \mathrm{~K}$ & $39.5 \pm 2.1 \mathrm{a}$ & $42.7 \pm 1.7 \mathrm{a}$ & $50.3 \pm 1.7 \mathrm{a}$ & $49.8 \pm 2.0 \mathrm{a}$ & $51.5 \pm 1.8 \mathrm{a}$ \\
& $42.7 \pm 1.8 \mathrm{a}$ & $43.6 \pm 2.4 \mathrm{a}$ & $48.5 \pm 3.2 \mathrm{a}$ & $34.9 \pm 2.7 \mathrm{c}$ & \\
\hline \multirow{2}{*}{ Number of } & Control & $13.0 \pm 1.5 \mathrm{a}$ & $13.0 \pm 1.0 \mathrm{a}$ & $11.7 \pm 0.9 \mathrm{a}$ & $13.3 \pm 1.8 \mathrm{a}$ & $9.3 \pm 0.7 \mathrm{a}$ \\
fruit & $1 \mathrm{~W} 0 \mathrm{~K}$ & $11.3 \pm 0.3 \mathrm{a}$ & $16.7 \pm 0.3 \mathrm{~b}$ & $12.7 \pm 0.7 \mathrm{a}$ & $10.0 \pm 1.0 \mathrm{ab}$ & $9.3 \pm 0.9 \mathrm{a}$ \\
& $0 \mathrm{~K}$ & $10.7 \pm 0.7 \mathrm{a}$ & $10.7 \pm 0.3 \mathrm{a}$ & $7.0 \pm 2.0 \mathrm{a}$ & $5.3 \pm 0.9 \mathrm{~b}$ & \\
\hline \multirow{2}{*}{ Total fruit } & Control & $519 \pm 51 \mathrm{a}$ & $530 \pm 69 \mathrm{ab}$ & $517 \pm 41 \mathrm{a}$ & $607 \pm 71 \mathrm{a}$ & $432 \pm 25 \mathrm{a}$ \\
yield (g) & $1 \mathrm{~W} 0 \mathrm{~K}$ & $447 \pm 16 \mathrm{a}$ & $712 \pm 9 \mathrm{a}$ & $637 \pm 37 \mathrm{a}$ & $498 \pm 53 \mathrm{a}$ & $481 \pm 9 \mathrm{a}$ \\
& $0 \mathrm{~K}$ & $456 \pm 53 \mathrm{a}$ & $465 \pm 55 \mathrm{~b}$ & $340 \pm 117 \mathrm{a}$ & $186 \pm 44 \mathrm{~b}$ & \\
\hline \multirow{2}{*}{ Soluble Solids } & Control & $6.9 \pm 0.1 \mathrm{a}$ & $6.6 \pm 0.1 \mathrm{a}$ & $6.5 \pm 0.1 \mathrm{a}$ & $6.2 \pm 0.1 \mathrm{a}$ & $5.6 \pm 0.1 \mathrm{a}$ \\
Content $(\%)$ & $1 \mathrm{~W} 0 \mathrm{~K}$ & $6.7 \pm 0.1 \mathrm{a}$ & $6.4 \pm 0.1 \mathrm{a}$ & $6.2 \pm 0.1 \mathrm{a}$ & $5.5 \pm 0.1 \mathrm{~b}$ & $5.2 \pm 0.1 \mathrm{~b}$ \\
& $0 \mathrm{~K}$ & $6.7 \pm 0.1 \mathrm{a}$ & $6.6 \pm 0.1 \mathrm{a}$ & $5.8 \pm 0.2 \mathrm{~b}$ & $4.9 \pm 0.3 \mathrm{c}$ & \\
\hline \multirow{2}{*}{ Water content } & Control & $92.7 \pm 0.1 \mathrm{a}$ & $92.4 \pm 0.1 \mathrm{a}$ & $92.7 \pm 0.1 \mathrm{a}$ & $93.0 \pm 0.1 \mathrm{a}$ & $93.7 \pm 0.1 \mathrm{a}$ \\
$(\%)$ & $1 \mathrm{~W} 0 \mathrm{~K}$ & $92.9 \pm 0.1 \mathrm{a}$ & $92.9 \pm 0.1 \mathrm{~b}$ & $93.1 \pm 0.1 \mathrm{~b}$ & $93.9 \pm 0.1 \mathrm{~b}$ & $94.0 \pm 0.1 \mathrm{~b}$ \\
& $0 \mathrm{~K}$ & $93.1 \pm 0.1 \mathrm{a}$ & $93.3 \pm 0.1 \mathrm{c}$ & $93.7 \pm 0.2 \mathrm{c}$ & $94.7 \pm 0.3 \mathrm{c}$ & \\
\hline
\end{tabular}

Each value shows the mean \pm standard error.

Means followed by the common letters under each trust were not significantly different according to the multiple test of Tukey $(P<0.05)$.

In the 5 th truss of $0 \mathrm{~K}$ treatment, no fruit were harvested.

by the treatment with potassium restriction. The sodium contents were $60^{-} 106 \mu \mathrm{g}$ in the $1 \mathrm{~W} 0 \mathrm{~K}$ treatment group and $88-179 \mu \mathrm{g}$ in the $0 \mathrm{~K}$ treatment group. The percentages were $128-200 \%$ and $187-332 \%$ of the control group in the 1 W0K and $0 \mathrm{~K}$ treatment groups.

Fresh weight of fruits and the total number of fruits harvested were not affected significantly by the two treatments with potassium restriction, except for the fourth and the fifth truss of the $0 \mathrm{~K}$ treatment group (Table 4). In the fourth truss of the $0 \mathrm{~K}$ treatment group, fresh weight and the total number of fruit were significantly lower than that in the control group. In the $1 \mathrm{~W} 0 \mathrm{~K}$ treatment group, the fresh weight in the fourth truss and the number of fruits in the second truss were higher than that in the control group. Overall, the total fruit yield was not changed significantly by the two treatments with potassium restriction, except for the fourth and the fifth trusses in the $0 \mathrm{~K}$ treatment 


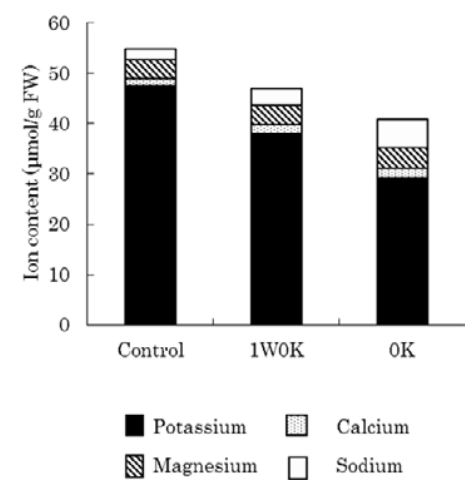

Fig. 2 Changes in total ion contents of potassium, calcium, magnesium and sodium of tomato at the harvest as affected by potassium restricted treatment. Each value shows the mean of all fruit in each treatment.

group.

Soluble solids content and water content were affected by the treatment with potassium restriction. Compared to that in the control group, the soluble solids content was significantly lower in the fourth and the fifth trusses of the 1 W0K treatment group and in the third and the fourth trusses of the $0 \mathrm{~K}$ treatment group. Water content was significantly higher than that in the control in the second to the fifth trusses of the $1 \mathrm{~W} 0 \mathrm{~K}$ treatment group and in the second to the fourth trusses of the $0 \mathrm{~K}$ treatment group.

The number of moles of sodium ions increased for tomatoes in the potassium-restricted groups (Fig. 2). However, the total number of moles in potassium-restricted group was $86^{-74 \%}$ of that in the control group by the $1 \mathrm{~W} 0 \mathrm{~K}$ and $0 \mathrm{~K}$ treatments, respectively.

\section{DISCUSSION}

The objective of this study was to apply low potassium cultivation method described in our previous study (Ogawa et al., 2007) to other leafy vegetables, and verify the success of this method with other vegetables. In addition, we aimed to verify a low potassium cultivation method for one of the vegetables, tomatoes, while still maintaining normal plant growth.

Potassium content was successfully reduced in leafy vegetables, with no significant change in fresh weight when using the hydroponical method in which potassium was applied in the early period and not applied during the last seven to ten days before harvest (Ogawa et al., 2007) (Tables 1 and 2). The potassium content for the "no potassium" group was $30-40 \%$ of the control group. Furthermore, the potassium content was reduced significantly by the $1 \mathrm{~W} 0 \mathrm{~K}$ and $0 \mathrm{~K}$ treatments with no decrease in fresh weight per fruit (Tables 3 and 4). Hafsi et al. (2011) reported that despite the presence of very low potassium concentrations in the culture medium, the amount of potassium in the plant tissues was sufficient to sustain the plant vegetative growth.

The total fruit yield of tomatoes decreased in the upper truss of the $0 \mathrm{~K}$ treatment group. The soluble solids content was decreased significantly and the water content was increased significantly in the upper truss of the "no potassium" group (Table 4). It has been reported that potassium deficiency can reduce stomatal aperture, thereby impairing $\mathrm{CO}_{2}$ fixation, disrupting the conversion of light energy to chemical energy, and the phloem export of photosynthates from the source to sink organs (Cakmak, 2005).

When potassium content was reduced drastically, sodium and magnesium contents were increased significantly in leafy vegetables (Table 1) and tomatoes (Table 3). It is suggested that the increments of these ions compensated for the reduction of potassium. The presence of sodium and 
magnesium ions is important in alleviating the effects of potassium deficiency. It is suggested that the increase in sodium and magnesium concentrations occurred in response to the decrease in potassium (Diem and Godbold, 1993; Pujos and Morard, 1997). Potassium ions and magnesium ions have similar roles in osmotic adjustment, enzyme activation, and cellular $\mathrm{pH}$ control (Marchner, 1995). It was showed that the absorption of magnesium was increased when the amount of potassium fertilization was reduced in soybeans (Itoh et al., 1997). Sodium ions could replace potassium ion in non-specific physiological and biochemical functions (Flowers and Läuchli, 1983). It was reported that substituting $20 \% \mathrm{NaCl}$ for $20 \% \mathrm{KCl}$ showed no significant effects on plant growth in spinach grown in sand culture (Tomemori et al., 2002). In this study, the total numbers of moles in potassium restricted treatments were lower than those in control and the decline in potassium ions was not explained sufficiently by the increase in the other three ions in red leaf lettuce, asparagus lettuce (Fig. 1), and tomato (Fig. 2). It is reported that other solutes, for example sugars and amino acids, contribute to osmotic adjustment (Ogawa and Yamauchi, 2006). It is considered that the absence of normal potassium levels resulted in increase in the concentration of these solutes.

The concentration of sodium increased with the reduction in potassium concentration. An increase in sodium intake is not advisable for dialysis patients, because it leads to hyperpiesia and edema. It is necessary to evaluate the benefits of the reduction of potassium against the risks of the increase of sodium intake for dialysis patients, whose potassium intake should be restricted to 1,500-2,000 mg per day (Agondi et al., 2011) and $\mathrm{NaCl}$ (equivalent to 2,000-3,200 mg sodium) intake should be restricted $5,000-8,000 \mathrm{mg}$ per day. Therefore, sodium intake must be limited to 1.3-1.6 times potassium intake.

In the present study, the potassium content per $1 \mathrm{~g}$ fresh weight of red leaf lettuce, asparagus lettuce, and komatsuna in the potassium-restricted groups reduced by 2.90, 2.17, and $2.69 \mathrm{mg}$ compared with the control group, respectively (Table 1), while the sodium contents increased by 0.95 , 0.44 , and $1.66 \mathrm{mg}$, respectively. Similarly in the tomatoes, the potassium content per $1 \mathrm{~g}$ fresh weight in the $1 \mathrm{~W} 0 \mathrm{~K}$ and $0 \mathrm{~K}$ treatment groups reduced by $0.37 \mathrm{mg}$ and $0.81 \mathrm{mg}$, respectively. At the same time, the sodium content increased by $0.03 \mathrm{mg}$ and $0.09 \mathrm{mg}$, respectively. Therefore, the reduction of potassium was greater than the increase in sodium in each plant. In addition, potassium intake can only be determined by a patient's diet. Consequently, eating food with low potassium content is an effective way to limit the potassium intake. On the other hand, limiting the amount of salt used is a more effective way of reducing sodium intake than concentrating only on eating foods with low sodium content. We conclude that the benefits of reducing the intake of potassium are greater than the risks of increasing the intake of sodium.

In this study, we demonstrated a cultivation method to reduce the potassium content of leafy vegetables without causing significant potassium deficiency symptoms. Potassium content was also successfully reduced in tomatoes, with no change in the fresh weight per fruit, although the total yield was reduced. These results will contribute to an improvement in the dietary quality of dialysis patients.

\section{REFERENCES}

Agondi, R. F., Gallani, M. C., Rodrigues, R. C., Cornelio, M. E. 2011. Relationship between beliefs regarding a low salt diet in chronic renal failure patients on dialysis. J. Ren. Nutr. 21: $160-168$.

Atkins, R. C., Zimmet, P. 2010. Diabetic Kidney Disease: Act Now or Pay Later-World Kidney Day, 11 March 2010. Ther. Apher. Dial. 14: 1-4.

Burrowes, J. D., Ramer, N. J. 2006. Removal of potassium from tuberous root vegetables by leaching. J. Ren. Nutr. 16: 304-311.

Burrowes, J. D., Ramer, N. J. 2008. Changes in potassium content of different potato varieties after cooking. J. Ren. Nutr. 18: 530-534. 


\section{A. OGAWA ET AL.}

Cakmak, I. 2005. The role of potassium in alleviating detrimental effects of abiotic stresses in plants. J. Plant Nutr. Soil Sci. 168: 521-530.

Diem, B., Godbold, D. L. 1993. Potassium, calcium and magnesium antagonism in clones of Populus trichocarpa. Plant Soil 155: 411-414.

Fageria, N. K., Baligar, V. C., Jones, C. A. 2010. Growth and mineral nutrition of field crops. CRC Press, New York.

Flowers, T. J., Läuchli, A. 1983. Sodium versus potassium: substitution and compartmentation. In "Inorganic Plant Nutrition. Encyclopedia of Plant Physiology, New Series” (ed. by Läuchli, A., Pirson, A.), pp. 651 -681 .

Fresenius Medical Care. 2011. Annual Report 2011. http://www.fmc-ag.com/files/GB2011_en.pdf

Hafsi, C., Atia, A., Lakhdar, A., Debez, A., Abdelly, C. 2011. Differential responses in potassium absorption and use efficiencies in the halophytes catapodium rigidum and hordeum maritimum to various potassium concentrations in the medium. Plant Prod. Sci. 14: 135-140.

Itoh, R., Yamagishi, J., Ishii, R. 1997. Effects of potassium deficiency on leaf growth, related water relations and accumulation of solutes in leaves of soybean plants. Jpn. J. Crop. Sci. 66: 691-697.

Marchner, H. 1995. Mineral nutrition of higher plants. Academic Press, London.

Ogawa, A., Taguchi, S., Kawashima, C. 2007. A cultivation method of spinach with a low potassium content for patients on dialysis. (in Japanese with English abstract) Jpn. J. Crop. Sci. 76: 232-237.

Ogawa, A., Yamauchi, A. 2006. Root osmotic adjustment under osmotic stress in maize seedlings. 2. Mode of accumulation of several solutes for osmotic adjustment in the root. Plant Prod. Sci. 9: 39-46.

Pujos, A., Morard, P. 1997. Effects of potassium deficiency on tomato growth and mineral nutrition at the early production stage. Plant Soil 189: 189-196.

Putcha, N., Allon, M. 2007. Management of hyperkalemia in dialysis patients. Semin Dial 20: 431-439.

Schachtman, D., Liu, W. 1999. Molecular pieces to the puzzle of the interaction between potassium and sodium uptake in plants. Trends Plant Sci. 4: 281-287.

Spital, A., Stems, R. H. 1988. Potassium homeostasis in dialysis patients. Semin Dial 1: 14-20.

Tomemori, H., Hamamura, K., Tanabe, K. 2002. Interactive effects of sodium and potassium on the growth and photosynthesis of spinach and komatsuna. Plant Prod. Sci. 5: 281-285.

Weiner, I. D., Wingo, C. S. 1998. Hyperkalemia: a potential silent killer. J. Am. Soc. Nephrol. 9: 1535-1543. 